\title{
A critical review of the outcome of Turco's One Stage Posteromedial Soft tissue release for Congenital Talipes Equino Vares (CTEV) in infancy
}

\author{
Authors \\ Dr Sunil S Menon, Dr Vivek Parameswara Sarma \\ Department of Paediatric Surgery, SAT Hospital \\ Govt Medical College, Thiruvananthapuram
}

\section{Introduction}

Congenital Talipes Equino Vares (CTEV) is a very commonly detected anomaly, charecterised by a wide spectrum of varying deformity. Milder deformities are amenable to non operative treatment by plaster of paris cast while more severe abnormalities require surgical correction. While the classical surgical correction by posteromedial soft tissue release (Turco's operation) is required in selected cases, many cases are now manged by the Ponsetti's technique.

\section{Aims}

To critically review and analyse the early outcome of Turco's One Stage Posteromedial Soft tissue release for CTEV in infancy.

\section{Materials and Methods}

A combined retrospective and prospective analysis of selected cases of CTEV operated between Jan 2011 to Jan 2015 at Department of Paediatric Surgery, SAT Hospital, Govt Medical College, Thiruvananthapuram and IMCH, Govt Medical College, Kozhikode.

Exclusion criteria: Age beyond one year, associated neuromuscular disorders, previous surgery (Tendo Achilles Tenotomy), Recurrent CTEV.

All CTEV were assessed from new born period. A below knee POP cast was used till 3 - 4 months of age depending on the degree of correction obtained. The cast was changed every 3-4 weeks.

At 4 months, the child was reassessed and placed on a KAF Orthotic, done from the department of physical medicine and rehabilitation. The child is periodically reviewed during this period.

None of the patients in this study group underwent above knee POP cast or surgeries like tendo achilles tenotomy. The child was finally reassessed at 9- 10 months to decide on the need for surgery. The cases that underwent surgery were moderate to severe deformities that were uncorrected with initial non operative treatment till $9-10$ months of age.

The preferred time of surgery was at about 10 months. In bilateral cases, the second foot was operated 3-4 weeks after the first surgery, along with above knee POP cast for the initially operated foot. Above knee POP cast was given during the initial two changes followed by below knee POP cast for a total of 2-3 months, according to severity of CTEV and extent of correction. The aim was to obtain corrected feet by one year so that the child 
can bear weight and be ambulant on the corrected feet with corrective shoes to maintain the correction. Limb physiotherapy and muscle strengthening exercises are advised by the department of physical medicine and rehabilitation.

24 surgeries were done on 15 patients. [Refer Table 1]. Surgery was done under general anaesthesia and caudal epidural block. A rubber tourniquet is used in all cases after squeezing blood down from the elevated limb to achieve good blanching. An extensive posteromedial soft tissue release is done with release of the contracted sheath of the tendons of Tibialis Posterior, Flexor Digitorum Longus, and Flexor Hallucis Longus. The contracted sheath of the neurovascular bundle is also released. $\mathrm{Z}$ plasty lengthening of achilles tendon is done. Graded correction is obtained on serial POP casting under anaesthesia.

Table 1 : Type of CTEV

\begin{tabular}{|c|c|}
\hline Type of CTEV & Total $=15$ \\
\hline Unilateral & 6 \\
\hline Bilateral & 9 \\
\hline
\end{tabular}

\section{Results}

The correction of foot achieved was assessed after 4-6 months of surgery and was assessed by a surgeon other than the operating surgeon and the result was photographed for comparison and follow up. The available follow up varied from 6 months to 18 months. The result was graded as good in 16, fair in 4 and poor in 2 cases.[ Refer Table 2 ]. The only significant complication was residual deformity in 3 feet and wound complication in 4 cases.[Refer Table 3]

Table 2 : Grading of the result of CTEV

\begin{tabular}{|l|c|}
\hline Grading of the result of CTEV & Number of cases $(\mathrm{n}=24)$ \\
\hline Good & $17(71 \%)$ \\
\hline Fair & $5(21 \%)$ \\
\hline Poor & $2(8 \%)$ \\
\hline
\end{tabular}

Table 3 : Complications after surgery

\begin{tabular}{|l|c|}
\hline Complications after surgery & Number of cases $(\mathrm{n}=24)$ \\
\hline Wound dehiscence & 2 \\
\hline Wound infection & 2 \\
\hline Significant residual deformity & 3 \\
\hline
\end{tabular}

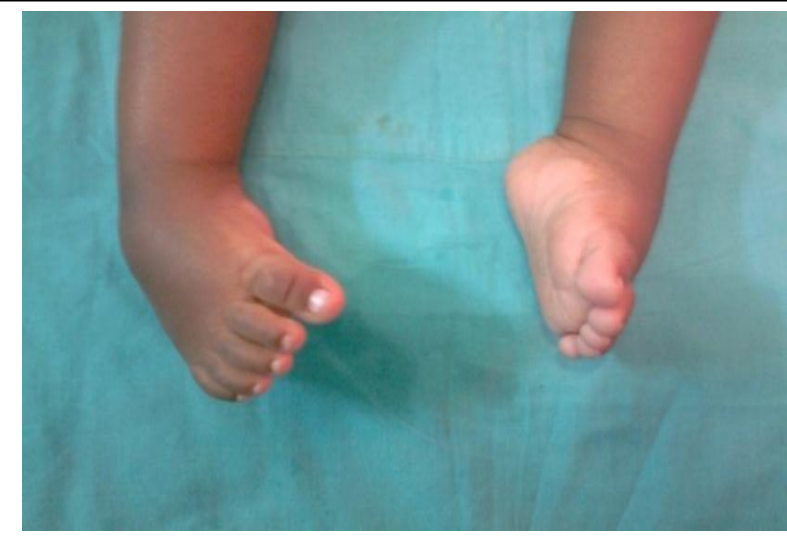

Figure 1: Preoperative photograph of bilateral CTEV

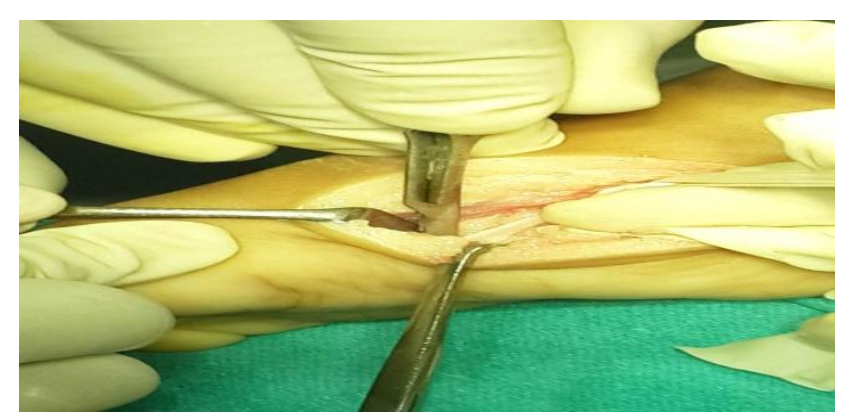

Figure 2 : Intraoperative photograph: release of tendon sheaths

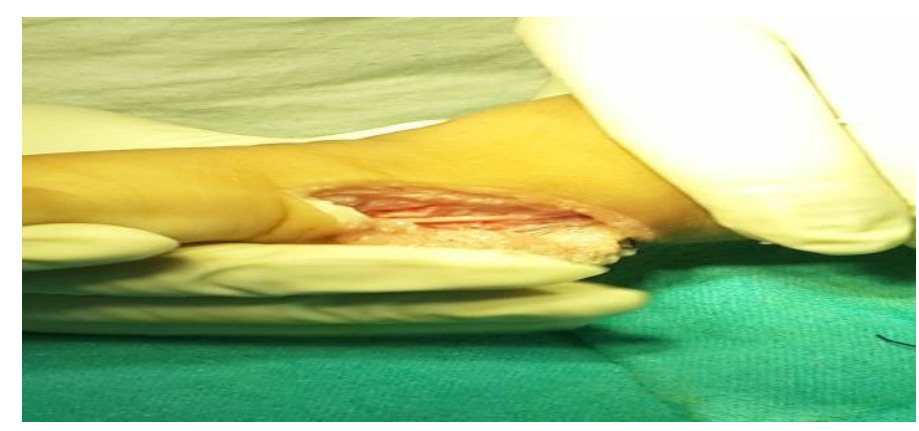

Figure 3 : Intraoperative photograph : release of contracted soft tissue

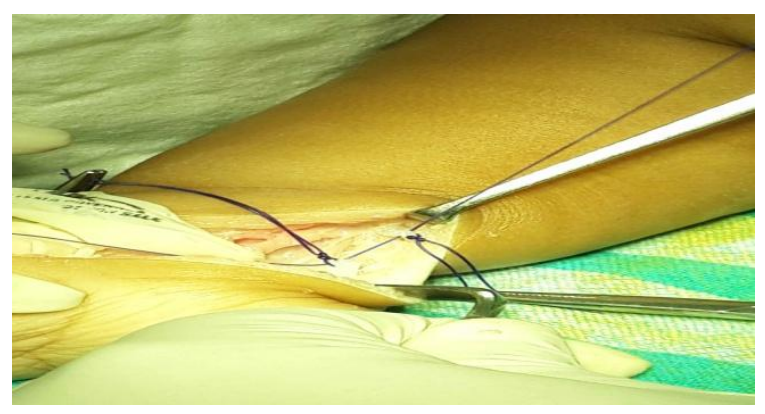

Figure 4: Intraoperative photograph: Z Plasty lengthening of Tendo Achilles 


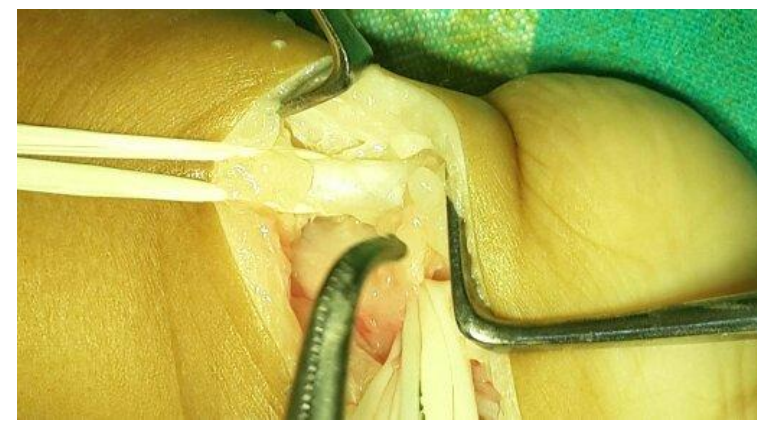

Figure 5 : Intraoperative photograph: release of tibialis posterior tendon

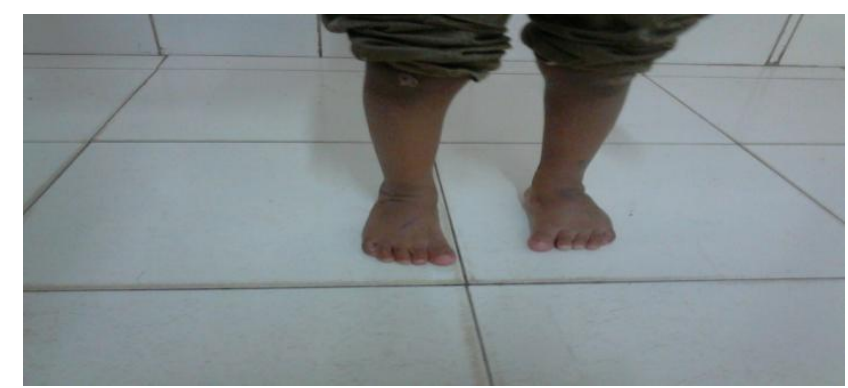

Figure 6: Post operative photograph after one year of surgery

\section{Conclusions}

Turco's One Stage Posteromedial Soft tissue release gives a good functional and cosmetic outcome in moderate to severe CTEV which are unresponsive to non operative treatment.

\section{References}

1 Surgical correction of resistant club foot: One stage Postero medial release with internal fixation Vincent $\mathrm{J}$ Turco Journal of Bone and joint surgery, Vol 53 A,No 3,April1971

2 Long term results after extensive soft tissue release in very sever congenital club foot (PIMD :26633817) Alkar F Louhem D, Bonnet F, Patte K Delpont M, Cottalorda J Ped Ortho 2017

3 Congental Idiopathic Talipes equino arus before and after walking age: Observations and strategy of treatmentfrom a series of 88 cases (PMID:26409466) Faldini C Trina F , NanniM Sanzarello I, Borghi R, Perna F J Orthop Traumatol 2016
4 Congenital Club Foot (PMID 27490755) HOsseinzadeh P, Milbrandt TJBJS Rev 2014

5 Long term results of comprehensive club foot release versus the Ponsetti method: which is better? (PMID: 24249539) Smith PA , Kuo KN , Graf AN, Krazac J ,Flanagan, A, Hassai S, Caudill AK, Dietz FR, Morcuende J, HarrisGF, Clin Orthop Relat Res 2014

6 The 100 classic papers of pediatric Ortopedic surgery : a bibliometric analysis (PMID 24048565) Kavanagh RG, KellyJC Kelly PM, Moore, J Bone joint Surg Am 2013

7 Update on club foot : Etiology and Management (PMID 19224303) Fransetti P, De MaioF, Russolillo L , Ippolito E Clin Orthop Relat Res 2009

8 Evaluation of disease specificinstrument for Idiopathic club foot outcome (PMID : 19159116) Dietz FR, Tyler MC, Leary KS, Damiano PC Clin Ortho Relat Res 2009. 